\title{
Harmfulness of root rot in the stands planted on formerly arable land and clear-cuts after annosum-infected pine forests in Chernihiv Polissya physiographic region of Ukraine
}

\author{
Viktor Tkach ${ }^{1}$, Oksana Tarnopilska ${ }^{1,2}$, Oleksiy Kobets ${ }^{1}$, Volodymyr Luk'yanets ${ }^{1}$, \\ Maksym Rumiantsev ${ }^{1}$, Iryna Obolonyk ${ }^{1 *}$, Sergiy Musienko ${ }^{2}$ \\ ${ }^{1}$ Ukrainian Research Institute of Forestry and Forest Melioration named after G. M. Vysotsky, 86, Pushkinska Street, Kharkiv, \\ 61024, Ukraine \\ ${ }^{2}$ O. M. Beketov National University of Urban Economy in Kharkiv, 17, Marshal Bazhanov Street, Kharkiv, 61002, Ukraine
}

\begin{abstract}
The study was conducted in pure Scots pine (Pinus sylvestris L.) forests and mixed forests of Scots pine and silver birch (Betula pendula Roth.) within the Chernihiv Polissya physiographic region of Ukraine. The aim of the study was a comparative analysis of forest mensuration characteristics and health condition of pine and mixed pine-birch stands planted on formerly arable lands and cutover areas after pine stands infected by annosum root rot. It was found that in pine stands planted on formerly arable land, the average diameter of living trees in the root rot disease focus was $1-6 \%$ larger and the average diameter of dead trees was $11-23 \%$ larger than those outside the disease focus. Due to the pathological loss inside the disease foci, the pine stand density was much lower - by $14-38 \%$ and the growing stock volume was 16-35\% less as compared to the outside areas. Mixed pine-birch stands (with a predominance of pine trees), established on the cutover areas after pine stands affected by root rot, had a $20 \%$ greater stock volume and the birch-pine stands (with birch predominance) in the clear-cuts had $18 \%$ greater stock volume than pure pine stands inside the root rot disease area. The pine trees were assessed as "weakened" in the mixed stands and as "severely weakened" in the pure pine stand inside the disease focus. The birch trees in mixed stands were characterized as "healthy".
\end{abstract}

Key words: Scots pine; health condition; root rot; disease focus

Editor: Andrej Kunca

\section{Introduction}

About 1 million hectares of forest stands were established in Ukraine between the 1950s and 1970s on formerly arable land. Most of the stands were pure crops of pine (Pinus sylvestris L.). In such stands, the whole complex of biogeocoenotic relations typically has not formed yet. Therefore, the conditions of habitat for pine forests are rather specific and do not correspond to their ecological needs. The practice of afforestation of the non-forest land indicates the low resistance of such stands to pathological factors, in particular, to the root rot caused by Heterobasidion annosum s.l. (Ladeyshchikova et al. 1974; Sierota 2013).

In numerous studies, the root rot has been described as the most dangerous and harmful disease of root systems and butt part of coniferous plants. It causes the stock volume reduction in stands (Woodward et al. 1998; Gar- belotto \& Gonthier 2013; Lapitan et al. 2013; Vedmid et al.2013; Musienko et al. 2018), predetermines their early degradation (Vollbrecht et al. 1994), provokes largescale pest outbreaks (Lyamtsev 2015), and increases fire hazard and worsens the soil protection, water conservation and sanitary functions of a forest (Bendz-Hellgren et al.1999). Also, root rot infected trees are non-resistant to wind damage (Woodward et al. 1998). According to Asiegbu et al. (2005), the economic losses associated with the Heterobasidion infection in Europe are estimated at 800 million euros per year.

In Ukraine, the area of coniferous forests affected by root rot is $13-16 \%$ of the total area of conifers in which pathological processes are detected (Ustsky et al. 2010). In Polissya zone, the area of forest disease foci (90.9 thousand hectares) has increased by $30 \%$ up to 117.3 thousand hectares since 2007. Pine forests infected by root rot account for $72 \%$ ( 84.7 thousand hectares) of the area 
of stands with pathological processes detected (Chudak 2014).

H. annosum s.l. is widespread in the conifer forests of the Northern Hemisphere, especially in Europe, North and Central America, Russia, China and Japan (BendzHellgren et al. 1999; Korhonen et al. 1998; Vasiliauskas et al. 2002; Dai et al. 2003; Asiegbu et al. 2005; Otrosina \& Garbelotto 2010; Worrall et al. 2010; Wang 2012; Sierota 2013). Primary infection of trees is initiated by basidiospores and conidia of the fungus. Basidiospores are formed in the fruiting bodies, and conidia, throughout the growing season, on the mycelium in the loci where rotting is on the surface of infected stumps or roots (Negrutskiy 1986; Woodward et al. 1998; Garbelotto \& Gonthier 2013). Basidiospores are formed when the average daily temperature exceeds $5^{\circ} \mathrm{C}$. They infect freshly-cut surface of the stumps, from which then mycelium develops and infects adjacent trees. During winter felling, the probability of stump infestation decreases by 95\% (Brandtberg et al. 1996).

The leading factors that cause the spread of root rot in pine forests on formerly arable land are the changes in physical (Ladeyshchikova et al. 1974), mechanical and biochemical properties of soil due to long-term agricultural use (Negrutskiy 1986; Vasiliauskas 1989; Artyukhovskiy 2000; Ladeyshchikova et al. 2001; Ustsky 2011; Sierota 2013; Lukyanets et al. 2019), as well as the specific nature of the growth and formation of pure dense pine stands planted in these conditions (Ladeyshchikova et al. 1974; Raspopina et al. 2013). Most often the fungus attacks pure pine stands of 11-40 years old growing in fresh infertile and fairly infertile pine site types (Volchenkova et al. 2012).

Biological methods of plant protection based on Phlebiopsis gigantea (Fr.) Mass. is known to be the most effective measure to prevent the spread of root rot (Rishbeth 1963). For example, the biological control agent Rotstop based on Phlebiopsis gigantea is widely used in European countries (Great Britain, Norway, Switzerland, Finland, Poland, Latvia, Belarus, etc.) in the form of a suspension or a dry product (Kenigsvalde et al. 2011; Volchenkova \& Zvyagintsev 2011; Sierota 2013; Kenigsvalde et al. 2016). For the conditions of the eastern part of Ukraine, the biological product Penioflorin has been developed based on a spore suspension of the local $P$. gigantea strains (Demchenko \& Sukhomlin 2000). However, due to economic difficulties, this agent is rarely used in Ukraine. Furthermore, since fruiting bodies of $H$. annosum s.l. are formed quite rarely in Ukrainian pine forests and only in years with sufficient precipitation, the spore infection of the pathogen plays a secondary role. Therefore, forestry interventions, mainly tending felling and sanitation felling, remain the primary means to control the disease. However, these measures are not particularly effective (Zvyagintsev et al. 2013).

Growing mixed and deciduous stands in abandoned agricultural land instead of pure pine ones is an effec- tive and future-oriented way to prevent the occurrence and spread of root rot. Such stands are more resistant to the disease. At the same time, they enable the formation of the natural composition of soil microbiota. The following tree species can be used for mixing with pine in fresh fairly infertile pine sites: Betula pendula Roth., Quercus rubra L., Quercus robur L., and Alnus incana (L.) Moench. Their proportion in these conditions must be at least 30 \% (Alekseev et al. 1981; Negrutsky 1986; Bilous 2006). To reduce the infection level and to prevent the spread of root rot and also to form the natural composition of soil microbiota in formerly arable land, Peri et al. (1990), Ladeyshchikova et al. (2001), and Lygis et al. (2004) proposed to plant silver birch stands as a pine forecrop in fresh and moist fairly infertile pine sites. The most resistant are sparse (up to 2.5 thousand stems per ha) middle-aged mixed planted stands including shrubs that have rich species composition and grow in fresh fairly infertile sites in the northern part of Ukraine (Fedorov 1991). In Scots pine stands that grow on primary forest soils, the disease occurs relatively rarely and does not cause significant damage (Vasiliauskas 1989).

Despite the over 100-year history of the root rot research, the causes of increased Scots pine susceptibility to annosum root rot in formerly arable land have not been finally identified and effective practices to control the disease have not been developed. Therefore, the study of the root rot impact on the forest mensurational characteristics and health condition of Scots pine and silver birch stands within the Chernihiv Polissya physiographic region of Ukraine is extremely relevant as well as the development of practices that prevent and control the disease.

The aim of the study was the comparative analysis of forest mensurational characteristics and health condition of pure and mixed pine stands established in abandoned agricultural land and in the clear-cuts after pine stands infected by annosum root rot.

\section{Materials and methods}

The study was conducted in August-October, 2017. Scots pine and silver birch stands were assessed within the Gorodnyanske Forestry Enterprise located in the Chernihiv Polissya physiographic region of Ukraine (Fig. 1). The site of the study is typical for this region.

Chernihiv Polissya physiographic region is a lowlying undulating plain. The overall flatness of the territory is disrupted by the valleys of the Dnieper, Desna, and Snov rivers. The climate of the region is moderately continental. Annual rainfall is $500-610 \mathrm{~mm}$. There are many lakes and swamps in the river valleys. The area of the swamps is $4.5 \%$ of the area of Chernihiv Polissya region. The widespread soils are sod-podzolic, bog, and gray forest ones. The forest cover of the region is the lowest compared to other Polissya regions and is about $18 \%$. 


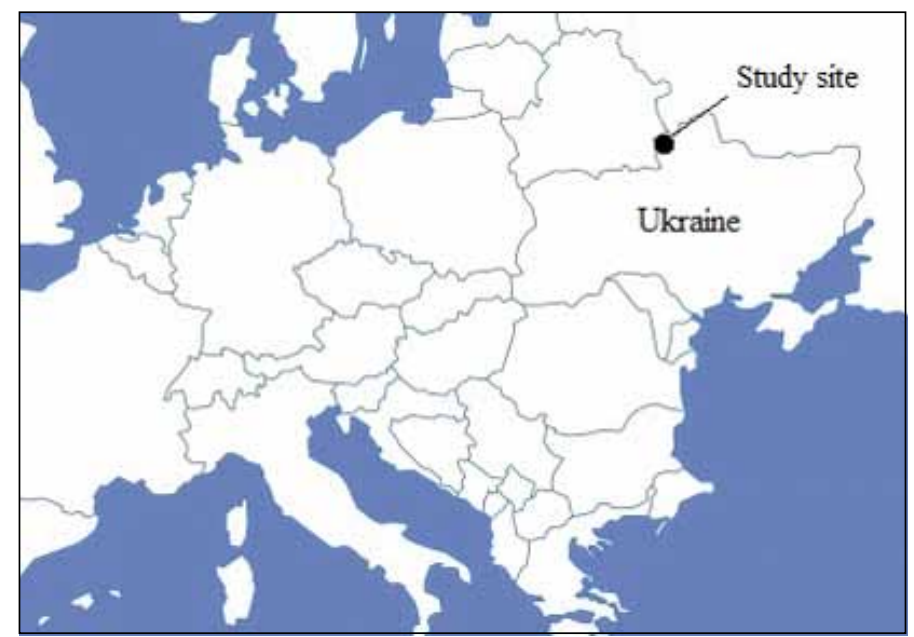

Fig. 1. Location of the study site (Latitude $51^{\circ} 52^{\prime} \mathrm{N}-51^{\circ} 45^{\prime} \mathrm{N}$; Longitude $31^{\circ} 15^{\prime} \mathrm{E}-31^{\circ} 30^{\prime} \mathrm{E}$ ).

The largest forest areas are located between the rivers of Dnieper and Desna and Snov and Desna. Scots pine forests and mixed English oak and Scots pine forests predominate (Marinich et al. 1985).

To investigate forest mensurational characteristics and health condition of the annosum-infected Scots pine stands planted on formerly arable land, seven sample plots were laid out in the part of the stand containing infected and dead trees (disease foci, DF). Seven sample plots were established as a control (C) in a relatively healthy part (i. e. without signs of deterioration) of the same stand (the area outside the disease foci) (Table 1). Also, to compare to the stands planted on formerly arable land, two sample plots were laid out within the disease foci and two sample plots outside the disease foci in the pine stands of the next generation replanted in clear-cuts after root rot infected stands. To compare the stand characteristics for annosum-infected pure pine stands with those for mixed ones planted in the clear-cuts after root rot infected stands, one sample plot was established in a mixed pine-birch stand and one sample plot in a mixed birch-pine stand (Table 2). These mixed stands were not infected by root rot.

The sample plots were established in the fresh fairly infertile pine sites. The size of the sample plot was determined, based on at least 200 trees of the main species on the plot. The trees were recorded by species, determining their diameters, assessing health condition and Kraft

Table 1. Forests mensurational characteristics of studied Scots pine stands established on formerly arable land.

\begin{tabular}{|c|c|c|c|c|c|c|c|c|c|c|}
\hline $\begin{array}{l}\text { Sample } \\
\text { plot number }\end{array}$ & Age [years] & Part of the stand & $\begin{array}{l}\text { Group of the } \\
\text { trees }\end{array}$ & $\begin{array}{l}\text { Stand density } \\
{\left[\text { stems ha }^{-1}\right]}\end{array}$ & $\begin{array}{c}\text { Average } \\
\text { diameter }[\mathrm{cm}]\end{array}$ & $\begin{array}{c}\text { Average height } \\
{[\mathrm{m}]}\end{array}$ & $\begin{array}{c}\text { Total stand } \\
\text { basal area } \\
{\left[\mathrm{m}^{2} \mathrm{ha}^{-1}\right]}\end{array}$ & $\begin{array}{c}\text { Growing } \\
\text { stock volume } \\
{\left[\mathrm{m}^{3} \mathrm{ha}^{-1}\right]}\end{array}$ & $\begin{array}{l}\text { Relative } \\
\text { density of } \\
\text { stocking }\end{array}$ & $\begin{array}{l}\text { Health } \\
\text { index } I\end{array}$ \\
\hline \multirow{2}{*}{$3-\mathrm{DF}$} & \multirow{4}{*}{20} & \multirow{2}{*}{ disease focus } & living & 1600 & 10.1 & 8.4 & 13.1 & 57 & 0.47 & \multirow{2}{*}{3.4} \\
\hline & & & dead & 753 & 7.1 & 7.4 & 2.9 & 11 & 0.10 & \\
\hline \multirow[b]{2}{*}{$3-C$} & & \multirow{2}{*}{ control } & living & 2563 & 9.5 & 8.8 & 19.0 & 88 & 0.69 & \multirow{2}{*}{2.3} \\
\hline & & & dead & 338 & 6.2 & 7.4 & 0.9 & 4 & 0.03 & \\
\hline & \multirow{4}{*}{33} & \multirow{2}{*}{ disease focus } & living & 982 & 18.2 & 17.8 & 25.8 & 214 & 0.66 & \multirow{2}{*}{2.3} \\
\hline 4-DF & & & dead & 182 & 16.4 & 17.1 & 3.8 & 30 & 0.10 & \\
\hline & & \multirow{2}{*}{ control } & living & 1148 & 18.1 & 18.3 & 30.3 & 259 & 0.76 & \multirow{2}{*}{1.5} \\
\hline $4-\mathrm{C}$ & & & dead & 52 & 13.8 & 16.2 & 0.7 & 6 & 0.02 & \\
\hline \multirow{2}{*}{ 5-DF } & \multirow{4}{*}{47} & \multirow{2}{*}{ disease focus } & living & 913 & 20.2 & 20.8 & 29.7 & 290 & 0.66 & \multirow{2}{*}{2.7} \\
\hline & & & dead & 225 & 16.0 & 18.4 & 4.5 & 39 & 0.10 & \\
\hline & & \multirow{2}{*}{ control } & living & 1111 & 20.0 & 21.2 & 34.8 & 343 & 0.76 & \multirow{2}{*}{1.7} \\
\hline $5-C$ & & & dead & 84 & 14.3 & 17.1 & 1.4 & 11 & 0.03 & \\
\hline \multirow{2}{*}{ 6-DF } & \multirow{4}{*}{50} & \multirow{2}{*}{ disease focus } & living & 775 & 21.4 & 20.9 & 27.6 & 265 & 0.61 & \multirow{2}{*}{3.2} \\
\hline & & & dead & 290 & 16.8 & 19.5 & 6.3 & 58 & 0.14 & \\
\hline & & \multirow{2}{*}{ control } & living & 960 & 20.8 & 21.8 & 32.7 & 329 & 0.71 & \multirow{2}{*}{2.4} \\
\hline $6-\mathrm{C}$ & & & dead & 100 & 12.9 & 19.0 & 13.0 & 12 & 0.03 & \\
\hline \multirow{2}{*}{ 7-DF } & \multirow{4}{*}{61} & \multirow{2}{*}{ disease focus } & living & 422 & 29.7 & 26.6 & 29.0 & 353 & 0.61 & \multirow{2}{*}{2.6} \\
\hline & & & dead & 113 & 22.3 & 24.2 & 4.4 & 51 & 0.09 & \\
\hline & & \multirow{2}{*}{ control } & living & 561 & 28.6 & 27.3 & 35.7 & 442 & 0.74 & \\
\hline $7-\mathrm{C}$ & & & dead & 38 & 18.2 & 23.7 & 1.0 & 11 & 0.02 & 1.4 \\
\hline & & & living & 530 & 27.7 & 23.8 & 32.0 & 346 & 0.67 & \\
\hline 8-DF & & disease focus & dead & 125 & 24.5 & 23.3 & 5.9 & 63 & 0.13 & 2.3 \\
\hline & 71 & & living & 695 & 26.5 & 24.2 & 37.9 & 417 & 0.81 & \\
\hline $8-C$ & & control & dead & 32 & 20.5 & 23.0 & 1.04 & 11 & 0.02 & 1.5 \\
\hline & & & living & 541 & 28.4 & 26.4 & 33.9 & 407 & 0.72 & \\
\hline 9-DF & & disease focus & dead & 273 & 19.2 & 22.5 & 7.9 & 83 & 0.16 & 3.2 \\
\hline & 81 & & living & 707 & 27.7 & 26.8 & 42.3 & 517 & 0.88 & \\
\hline $9-\mathrm{C}$ & & control & dead & 43 & 16.0 & 20.6 & 0.9 & 9 & 0.02 & 2.1 \\
\hline
\end{tabular}


Table 2. Forests mensurational characteristics of the stands established on clear-cuts after annosum-infected pine stands.

\begin{tabular}{|c|c|c|c|c|c|c|c|c|c|c|}
\hline $\begin{array}{l}\text { Sample plot } \\
\text { number }\end{array}$ & Age [years] & Composition & Species & $\begin{array}{l}\text { Group of } \\
\text { the trees }\end{array}$ & $\begin{array}{l}\text { Stand density } \\
{\left[\text { stems ha }{ }^{-1}\right]}\end{array}$ & $\begin{array}{c}\text { Average } \\
\text { diameter }[\mathrm{cm}]\end{array}$ & $\begin{array}{l}\text { Average height } \\
{[\mathrm{m}]}\end{array}$ & $\begin{array}{c}\text { Growing stock } \\
\text { volume } \\
{\left[\mathrm{m}^{3} \mathrm{ha}^{-1}\right]}\end{array}$ & $\begin{array}{c}\text { Relative density } \\
\text { of stocking }\end{array}$ & $\begin{array}{l}\text { Health index } \\
\text { Ic }\end{array}$ \\
\hline \multirow{4}{*}{ 14-DF } & \multirow{8}{*}{29} & \multirow{4}{*}{$90 \% \mathrm{Sp} 10 \% \mathrm{Sb}$} & \multirow[b]{2}{*}{ Sp } & living & 1123 & 15.2 & 14.3 & 134 & 0.52 & \multirow{2}{*}{2.6} \\
\hline & & & & dead & 165 & 11.9 & 13.0 & 12 & 0.05 & \\
\hline & & & \multirow{2}{*}{$\mathrm{Sb}$} & living & 207 & 10.1 & 13.5 & 10 & 0.06 & \multirow{2}{*}{1.1} \\
\hline & & & & dead & - & - & - & - & - & \\
\hline \multirow{4}{*}{$14-C$} & & \multirow{4}{*}{$90 \% \mathrm{Sp} 10 \% \mathrm{Sb}$} & \multirow{2}{*}{$\mathrm{Sp}$} & living & 1730 & 15.6 & 16.3 & 255 & 0.83 & \multirow{2}{*}{1.6} \\
\hline & & & & dead & 67 & 10.1 & 14.1 & 3 & 0.01 & \\
\hline & & & \multirow{2}{*}{$\mathrm{Sb}$} & living & 244 & 12.9 & 18.1 & 28 & 0.12 & \multirow{2}{*}{1.0} \\
\hline & & & & dead & - & - & - & - & - & \\
\hline \multirow{2}{*}{ 11-DF } & \multirow{4}{*}{49} & \multirow{2}{*}{$100 \% \mathrm{Sp}$} & \multirow{2}{*}{ Sp } & living & 597 & 22.6 & 20.7 & 228 & 0.52 & \multirow{2}{*}{2.7} \\
\hline & & & & dead & 113 & 19.9 & 20.8 & 35 & 0.08 & \\
\hline \multirow{2}{*}{$11-\mathrm{C}$} & & \multirow{2}{*}{$100 \% \mathrm{Sp}$} & \multirow{2}{*}{$\mathrm{Sp}$} & living & 940 & 22.0 & 20.5 & 334 & 0.80 & \multirow{2}{*}{1.7} \\
\hline & & & & dead & 95 & 14.3 & 17.8 & 13 & 0.03 & \\
\hline \multirow{4}{*}{10} & \multirow{4}{*}{48} & \multirow{4}{*}{$50 \% \mathrm{Sp} 50 \% \mathrm{Sb}$} & Sn & living & 241 & 25.5 & 22.9 & 129 & 0.26 & \multirow{2}{*}{2.3} \\
\hline & & & Sp & dead & 30 & 12.9 & 17.0 & 3 & 0.01 & \\
\hline & & & \multirow{2}{*}{$\mathrm{Sb}$} & living & 567 & 18.9 & 20.2 & 155 & 0.55 & \multirow{2}{*}{1.4} \\
\hline & & & & dead & 9 & 11.3 & 15.3 & 1 & - & \\
\hline \multirow{4}{*}{12} & \multirow{4}{*}{49} & \multirow{4}{*}{$80 \% \mathrm{Sb} 20 \% \mathrm{Sp}$} & & living & 990 & 17.1 & 21.9 & 231 & 0.74 & \multirow{3}{*}{1.5} \\
\hline & & & $\mathrm{Sb}$ & dead & 74 & 9.5 & 16.5 & 4 & 0.02 & \\
\hline & & & \multirow{2}{*}{ Sp } & living & 142 & 19.6 & 23.2 & 47 & 0.09 & \\
\hline & & & & dead & 20 & 15.2 & 20.7 & 3 & 0.01 & 2.3 \\
\hline
\end{tabular}

classes. The tree diameters were measured with a caliper at breast height (1.3 $\mathrm{m}$ above ground) within the accuracy of $0.1 \mathrm{~cm}$. The average diameter of the trees was determined by dividing the total basal area of each species by the corresponding total number of stems. According to the calculated basal area of the average tree, the average diameters for all species were determined.

The tree heights were measured in field conditions using IU-1M hypsometer. The average height of the species predominating in the stand composition was determined graphically by the average diameter of the trees of this species. To develop the height curve, we measured the height of 25-30 trees, which were distributed by diameter classes in proportion to the total basal areas of trees in the sample plot. For other species, the height was measured for 10-15 trees close to a medium-sized tree.

The health condition of the stand was described by the health condition index $I_{c}$ calculated by the formula [1] (Tarnopilska et al. 2018):

$$
I_{c}=\frac{K_{1} n_{1}+K_{2} n_{2}+\cdots \ldots+K_{6} n_{6}}{N}
$$

where: $K_{1}, \ldots, K_{6}$ - the category of the health condition of the trees (from 1 st to 6 th) $n_{1}, \ldots, n_{6}-$ the number of trees of the given health condition category; $N$ - the total number of recorded trees in the sample plot.

We assessed the health condition of the trees using 6 categories, namely: the $1^{\text {st }}$ - trees without signs of damage, the $2^{\text {nd }}$ - weakened trees, the $3^{\text {rd }}$ - severely weakened trees, the $4^{\text {th }}-$ dying trees, the $5^{\text {th }}-$ standing dead trees died over the present year, and the $6^{\text {th }}$ - standing dead trees died over recent years (Table 3 ).

The root rot disease focus is an area occupied by a group of severely weakened and dying trees of $3^{\text {rd }}$ and $4^{\text {th }}$ categories of health condition, including gaps resulting from the sanitation felling of the trees damaged by annosum root rot (Fig. 2a). The area outside the disease foci (control) is a healthy part of the stand, not disturbed by the pathogenic loss of trees (Fig. 2b). The disease-produced loss of forest consists of severely weakened and dying trees and fresh and old standing dead trees, i.e. the trees of the $3^{\text {rd }}, 4^{\text {th }}, 5^{\text {th }}$ and $6^{\text {th }}$ health condition categories (Sanitary Forests Regulations in Ukraine 2016). During the study, the type of dieback in the stands was defined as follows: focal dieback, when the foci of dying were formed; diffuse dieback, with individual trees damaged by root rot and stem pests; and mixed type of dieback, with the presence of focal and diffuse diebacks (Ladeyshchikova et al. 2001).

Detection of $H$. annosum s.l. was carried out using strains isolated from Pinus sylvestris by conidiospore germination. Trees visually damaged by root rot were used for sampling with cork borer from stump. Isolated strains grown on Hagem agar (Stenlid 1985) were determined to intersterility group by somatic incompatibility and PCR analysis (unpublished data) resulted in detection of $H$. annosum s.s.

The degree of differentiation of trees in stands was assessed according to the following Kraft's classification (Avery \& Burkhart 2002; Tarnopilska et al. 2018): $1^{\text {st }}$ class - predominant, exceptionally large trees; their crowns extend above the general level of the canopy; they

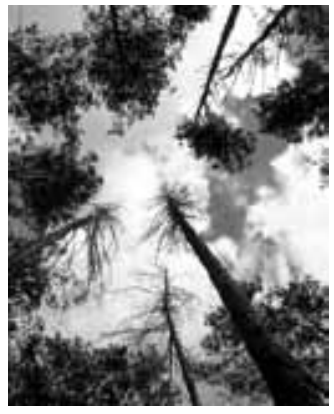

a)

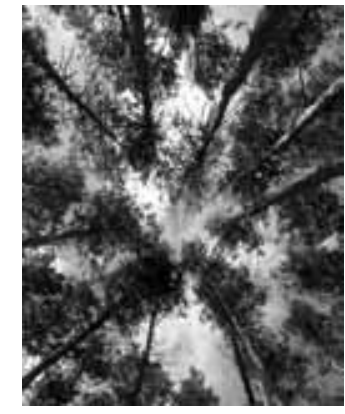

b)
Fig. 2. Planted 71-year-old pine stand inside root rot disease focus, 8-DF (a) and outside the disease focus, 8-C (b). 
Table 3. Scale applied in the assessment of health condition of Scots pine trees.

\begin{tabular}{|c|c|c|c|c|c|c|}
\hline \multirow[b]{2}{*}{ Category of health condition } & \multirow[b]{2}{*}{$\begin{array}{l}\text { Health condition } \\
\text { index range }\end{array}$} & \multirow[b]{2}{*}{ Canopy openness } & \multicolumn{2}{|c|}{ Degree of needle development } & \multirow[b]{2}{*}{ Needle colour } & \multirow[b]{2}{*}{ Degree of stand damage } \\
\hline & & & $\%$ & $\begin{array}{c}\text { Distribution of needles } \\
\text { over shoots }\end{array}$ & & \\
\hline $1^{\text {st }}-$ without signs of damage & $1.00-1.50$ & dense canopy & $90-100$ & no signs of deterioration & green & none \\
\hline $2^{\text {nd }}-$ weakened & $1.51-2.50$ & open canopy & $66-90$ & no signs of deterioration & green, light-green & weak \\
\hline $3^{\text {rd }}-$ severely weakened & $2.51-3.50$ & much open canopy & $33-66$ & concentrated & light-green & medium \\
\hline $4^{\text {th }}$ - dying & $3.51-4.50$ & much open canopy & 33 & concentrated & yellowish or yellow-green & significant \\
\hline $\begin{array}{l}5^{\text {th }}-\text { standing dead trees died over } \\
\text { the present year }\end{array}$ & $4.51-6.00$ & 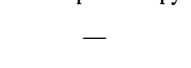 & 0 & no living needles & grey, yellow or reddish-brown & extreme \\
\hline $\begin{array}{l}6^{\text {th }}-\text { standing dead trees died over } \\
\text { recent years }\end{array}$ & $4.51-6.00$ & - & 0 & no living needles & - & extreme \\
\hline
\end{tabular}

have the largest, fullest crowns in the stand and thicker trunks; $2^{\text {nd }}$ - dominant trees; their crowns make up the general level of the canopy; generally, they are shorter than the predominant trees and have straight trunks; $3^{\text {rd }}$ - subdominant trees; they have the same height as the dominant trees but are relatively weakly developed and restricted often with other trees, there are some signs of suppression; $4^{\text {th }}-$ suppressed trees, with crowns restricted on all sides or on two sides, or with one-sided development; their tops reach only the lower part of the canopy of the dominant trees; $5^{\text {th }}$ class - the trees completely under the canopy of the dominant trees; dying and dead trees.

The site class of the stands (the productivity indicator depending on the soil fertility or site conditions) was determined using Orlov's site class scales developed on the basis of height, age, and origin of stands (Hrom 2007). Stand basal area (or a quantitative measure of the degree of crowding within the stand) was found as the sum of the basal area of all live trees in a stand per hectare $\left(\mathrm{m}^{2} \mathrm{ha}^{-1}\right)$. The relative density of stocking of a stand was calculated as the ratio of the stand basal area to the basal area of the 'normal' stand (Shvydenko et al. 1987). Growing stock volume was defined as the volume of all living trees per unit area $\left(\mathrm{m}^{3} \mathrm{ha}^{-1}\right)$, and the stand density as the number of living trees per unit area (stems ha-1) (Hrom 2007).

Peculiarities of the stand structure are described by the curve of tree distribution in natural diameter classes. Natural diameter classes are the diameter classes of the trunks, expressed in decimal fractions of average stand diameter. The distribution of trees by the natural diameter classes is a generalized variation series describing the variability of tree diameter within stands and the representation of certain diameter classes. In healthy stands with different composition, the distribution of trees by natural diameter classes was found to be approximately the same (Mashkovsky 2015). The skewness and kurtosis coefficients for the variational series (Hammer et al. 2001) were calculated to assess the impact of annosum root rot on the distribution of trees by natural diameter classes in the infected pine stands (Tables 4, 5).

\section{Results}

To specify the structure of the part of pine stands in the root rot foci, the natural diameter classes distribution within the disease foci was compared to that within the control plots. The analysis of the distribution of trees by natural diameter classes (Tables 6,7) indicated that the distribution curves were close to normal in the vast majority of sample plots, both in the disease foci and in the control (Tables 4, 5). The skewness of the distributions was positive and significant in the sample plots 4-DF, 8-DF, and 6-C. This means that most trees have diameters smaller than the average diameter. The kurtosis of the tree distrubution was negative and significant in all sample plots, except for 4-DF, 8-DF, 7-C, and 9-C.

In planted pine stands, the type of the dieback resulting from root rot damage was found to depend on the age of the stand. The distribution of the disease was diffuse in the young stands up to the age of 35 (3-DF and 4-DF sample plots) and mixed in the stands up to 50 years old (5-DF). In older stands, it became focal (6-DF, 7-DF, 8-DF, and 9-C).

Table 4. Results of statistical processing of the trees distribution by the natural diameter classes in the disease foci.

\begin{tabular}{|c|c|c|c|c|c|c|c|c|}
\hline \multirow{2}{*}{ Statistical indicator } & \multicolumn{8}{|c|}{ Sample plots } \\
\hline & $3-\mathrm{DF}$ & 4-DF & $5-\mathrm{DF}$ & $6-\mathrm{DF}$ & $7-\mathrm{DF}$ & 8-DF & 9-DF & $11-\mathrm{DF}$ \\
\hline Kurtosis & -1.466 & -0.061 & -1.589 & -1.017 & -1.037 & -0.368 & -1.498 & -1.288 \\
\hline Critical value of kurtosis $\left(s t_{0.05}\right)$ & 0.863 & 0.890 & 0.873 & 0.863 & 0.873 & 0.873 & 0.873 & 0.873 \\
\hline Skewness & 0.270 & 0.930 & 0.440 & 0.701 & 0.505 & 1.009 & 0.396 & 0.229 \\
\hline Critical value of skewness $\left(s t_{0.05}\right)$ & 0.711 & 0.711 & 0.711 & 0.711 & 0.711 & 0.711 & 0.711 & 0.711 \\
\hline
\end{tabular}

Table 5. Results of statistical processing of the distribution of trees by the natural diameter classes in the control sample plots.

\begin{tabular}{|c|c|c|c|c|c|c|c|c|}
\hline \multirow{2}{*}{ Statistical indicator } & \multicolumn{8}{|c|}{ Sample plots } \\
\hline & $3-\mathrm{C}$ & $4-C$ & 5-C & $6-\mathrm{C}$ & $7-\mathrm{C}$ & $8-C$ & 9-C & $11-\mathrm{C}$ \\
\hline Kurtosis & -1.065 & -1.798 & -1.504 & 1.197 & -0.862 & -1.322 & -0.584 & -1.738 \\
\hline Critical value of kurtosis $\left(s t_{0.05}\right)$ & 0.863 & 0.890 & 0.890 & 0.873 & 0.873 & 0.890 & 0.873 & 0.873 \\
\hline Skewness & 0.356 & 0.502 & 0.428 & 1.597 & 0.697 & 0.406 & 0.397 & -0.112 \\
\hline Critical value of skewness $\left(s t_{0.05}\right)$ & 0.711 & 0.711 & 0.711 & 0.711 & 0.711 & 0.711 & 0.711 & 0.711 \\
\hline
\end{tabular}


Table 6. Actual distribution of trees by the natural diameter classes in the disease foci (\%).

\begin{tabular}{|c|c|c|c|c|c|c|c|c|}
\hline \multirow{2}{*}{ Natural diameter classes } & \multicolumn{8}{|c|}{ Sample plots } \\
\hline & 3-DF & $4-\mathrm{DF}$ & 5-DF & 6-DF & $7-\mathrm{DF}$ & 8-DF & 9-DF & 11-DF \\
\hline$\overline{0.1}$ & 1.5 & 0 & 0 & 0 & 0 & 0 & 0 & 0 \\
\hline 0.2 & 2.0 & 0 & 0 & 0.5 & 0 & 0 & 0 & 0 \\
\hline 0.3 & 6.0 & 0 & 0 & 0 & 0.8 & 0 & 1.3 & 0 \\
\hline 0.4 & 8.5 & 0 & 0.5 & 5.6 & 0.8 & 0 & 3.1 & 0.7 \\
\hline 0.5 & 10.0 & 2.3 & 3.3 & 4.2 & 7.3 & 1.2 & 10 & 6.6 \\
\hline 0.6 & 9.5 & 3.1 & 9.3 & 7.5 & 14.6 & 4.4 & 10 & 8.6 \\
\hline 0.7 & 11.5 & 12.5 & 11.5 & 13.6 & 13.9 & 7.6 & 11.1 & 10.4 \\
\hline 0.8 & 7.0 & 10.2 & 15.9 & 9.9 & 9.8 & 20.3 & 11.7 & 15.9 \\
\hline 0.9 & 9.5 & 21.9 & 14.3 & 12.2 & 14.6 & 21.1 & 15.1 & 9.3 \\
\hline 1.0 & 4.5 & 10.9 & 12.7 & 13.1 & 7.3 & 16.5 & 14.7 & 12.6 \\
\hline 1.1 & 5.5 & 21.1 & 14.9 & 16.9 & 9.8 & 11.5 & 10.7 & 11.8 \\
\hline 1.2 & 6.0 & 7.8 & 8.8 & 10.8 & 6.6 & 9.6 & 5.3 & 10.7 \\
\hline 1.3 & 9.5 & 6.3 & 3.9 & 1.4 & 4.9 & 3.2 & 3.7 & 6.3 \\
\hline 1.4 & 2.5 & 3.1 & 1.7 & 2.8 & 5.6 & 1.2 & 2.4 & 3.7 \\
\hline 1.5 & 2.5 & 0.8 & 0.5 & 0.9 & 0.8 & 2 & 0.4 & 1.8 \\
\hline 1.6 & 1.0 & 0 & 2.2 & 0 & 1.7 & 0.6 & 0 & 0.7 \\
\hline 1.7 & 1.0 & 0 & 0.5 & 0 & 1.7 & 0.6 & 0.4 & 0.7 \\
\hline 1.8 & 1.0 & 0 & 0 & 0.5 & 0 & 0 & 0 & 0 \\
\hline 1.9 & 1.0 & 0 & 0 & 0 & 0 & 0 & 0 & 0 \\
\hline 2.0 & 0.0 & 0 & 0 & 0 & 0 & 0 & 0 & 0 \\
\hline
\end{tabular}

Table 7. Actual distribution of trees by natural diameter classes in the control plots (\%).

\begin{tabular}{|c|c|c|c|c|c|c|c|c|}
\hline \multirow{2}{*}{ Natural diameter classes } & \multicolumn{8}{|c|}{ Sample plots } \\
\hline & $3-\mathrm{C}$ & $4-\mathrm{C}$ & $5-\mathrm{C}$ & $6-\mathrm{C}$ & $7-\mathrm{C}$ & $8-C$ & $9-\mathrm{C}$ & $11-\mathrm{C}$ \\
\hline 0.1 & 0.4 & 0 & 0 & 0 & 0 & 0 & 0 & 0 \\
\hline 0.2 & 3.5 & 0 & 0 & 0 & 0 & 0 & 0 & 0 \\
\hline 0.3 & 2.6 & 0 & 0 & 0.7 & 0 & 0 & 0 & 0 \\
\hline 0.4 & 10.4 & 0 & 0 & 3.1 & 0.8 & 0 & 1.9 & 0.5 \\
\hline 0.5 & 8.6 & 0.3 & 0.9 & 3.8 & 2.3 & 0 & 0 & 3.9 \\
\hline 0.6 & 6.5 & 2.2 & 6.2 & 6.3 & 5.5 & 2.2 & 12.4 & 9.7 \\
\hline 0.7 & 6.1 & 6.9 & 11.5 & 4.4 & 11.2 & 10.9 & 10.5 & 14 \\
\hline 0.8 & 11.2 & 13.4 & 13.2 & 12 & 15.8 & 21 & 8.5 & 13.5 \\
\hline 0.9 & 10.8 & 18.1 & 13.2 & 18.2 & 19 & 18.8 & 11.5 & 13.5 \\
\hline 1.0 & 4.8 & 19.6 & 18.1 & 23.8 & 14.3 & 12.2 & 20.9 & 11.6 \\
\hline 1.1 & 8.6 & 19.6 & 18.5 & 10.1 & 11.8 & 14.4 & 10.5 & 10.1 \\
\hline 1.2 & 4.3 & 17 & 12.3 & 5 & 8 & 12.2 & 15.2 & 11.6 \\
\hline 1.3 & 7.4 & 2.2 & 3.5 & 7.5 & 5.5 & 4.4 & 6.7 & 4.8 \\
\hline 1.4 & 3.9 & 0.3 & 1.3 & 2.5 & 2.3 & 1.5 & 1.9 & 5.3 \\
\hline 1.5 & 5.2 & 0.3 & 0 & 0.7 & 1.7 & 2.2 & 0 & 1.4 \\
\hline 1.6 & 1.7 & 0 & 1.3 & 1.2 & 1.7 & 0 & 0 & 0 \\
\hline 1.7 & 1.7 & 0 & 0 & 0.7 & 0 & 0 & 0 & 0 \\
\hline 1.8 & 0.9 & 0 & 0 & 0 & 0 & 0 & 0 & 0 \\
\hline 1.9 & 1.3 & 0 & 0 & 0 & 0 & 0 & 0 & 0 \\
\hline 2.0 & 0 & 0 & 0 & 0 & 0 & 0 & 0 & 0 \\
\hline
\end{tabular}

\subsection{Pine stands planted on formerly arable land}

For pine stands planted on abandoned agricultural land, a direct relationship was found between the age of the stand and the average diameter as well as between the age and average height of the trees, both dead and living. The average diameter of the living trees in the disease focus was $1-6 \%$ larger compared to the control (outside the disease focus) because of larger vital space contributing to the increase of radial increment of trees. However, this difference was not significant.

In root rot disease focus, there was dieback of thicker trees as compared to the control. Also, the difference between the average diameters of dead trees inside and outside the disease focus was significant and varied within 11-23\% (Fig. 3). In the disease focus, the average height of living trees was 2-5\% lower in comparison with the control. On the contrary, the height of the dead trees inside the root rot focus was up to $8 \%$ higher compared to that outside it as in the disease focus the trees with larger diameter were dying (Fig. 4).
In the root rot disease foci, due to the pathological mortality, the density of the pine stand was much smaller, by $14-38 \%$ and the growing stock volume was $16-35 \%$ lower as against pine stand outside the disease foci (Fig. 5). In the control areas, the growing stock of pine stand unevenly increased with age, and the number of trees decreased.

The negative impact of annosum root rot is evidenced by the increase in the stock of standing dead trees (Fig. $6)$. For example, the stock of dead trees in the controls was small and varied within $4-12 \mathrm{~m}^{3} \mathrm{ha}^{-1}$. In the disease foci, it increased from $11 \mathrm{~m}^{3} \mathrm{ha}^{-1}$ in 21 -year-old stand to $83 \mathrm{~m}^{3} \mathrm{ha}^{-1}$ in 81-year-old one. In the 61-year-old pine stand, the stock of dead trees decreased slightly to $51 \mathrm{~m}^{3} \mathrm{ha}^{-1}$ due to the recent sanitation felling in it, which insignificantly influenced the general trend.

For pure Scots pine stands planted on formerly arable land the health condition index varied from 2.3 (weakened stand) to 3.4 (severely weakened stand) within the disease focus and from 1.4 (healthy stand) to 2.4 (weakened stand) in the control (Table 1). 


\subsection{Stands planted on clear-cuts after annosum-infected pine forests}

All mensurational indicators for the parts of the stands within root rot disease foci showed significantly lower rates than those outside them, due to the negative effects of the disease. For example, in the mixed 29-year-old stand, the average diameter and height within the dis- ease focus (14-DF) were below the control (14-C) by $3 \%$ and $12 \%$ respectively for Scots pine and by $22 \%$ and $25 \%$ for silver birch. The differences in the stand density inside and outside the disease focus were $35 \%$ for Scots pine and $15 \%$ for silver birch, in relative density of stocking they were $37 \%$ and $50 \%$ respectively; the growing stock differences were $47 \%$ and $64 \%$ for pine and birch respectively. Such differences were due to significant

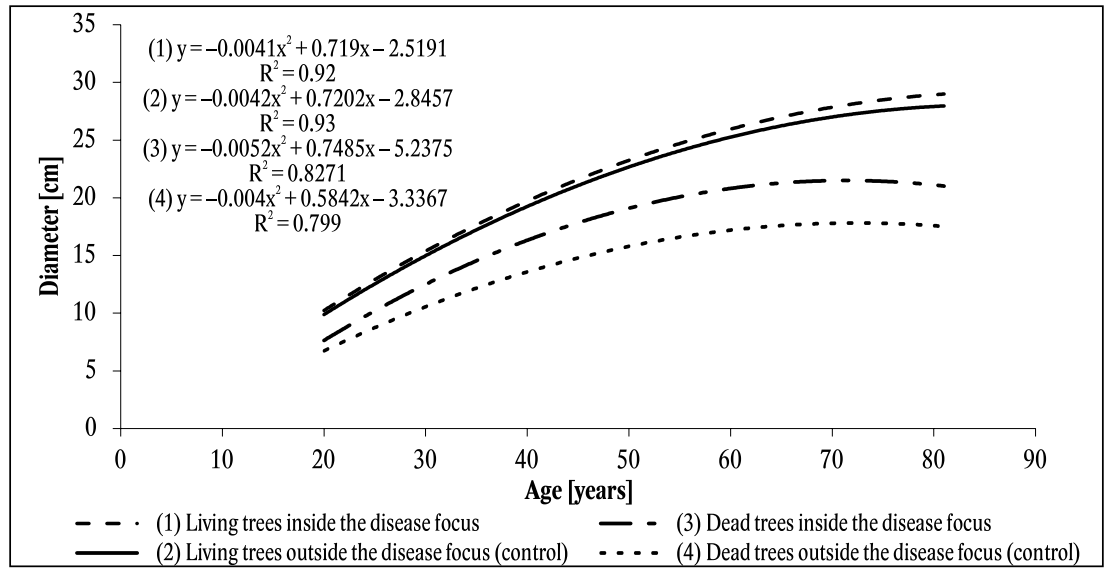

Fig. 3. Average diameters of dead and living pine trees inside and outside annosum root rot disease foci depending on stand age.

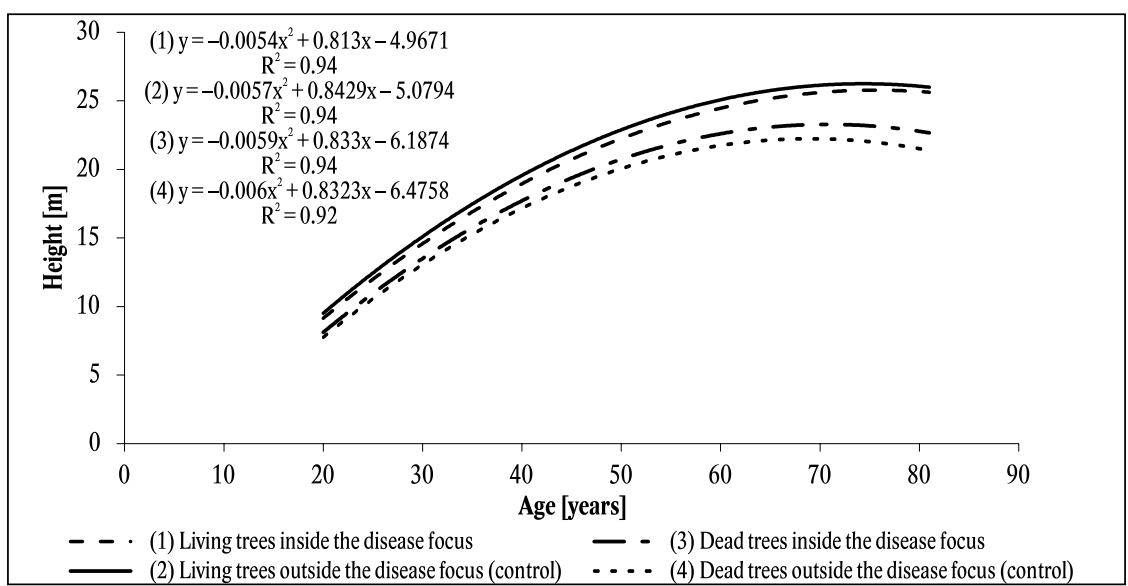

Fig. 4. Average heights of dead and living pine trees inside and outside annosum root rot disease foci depending on stand age.

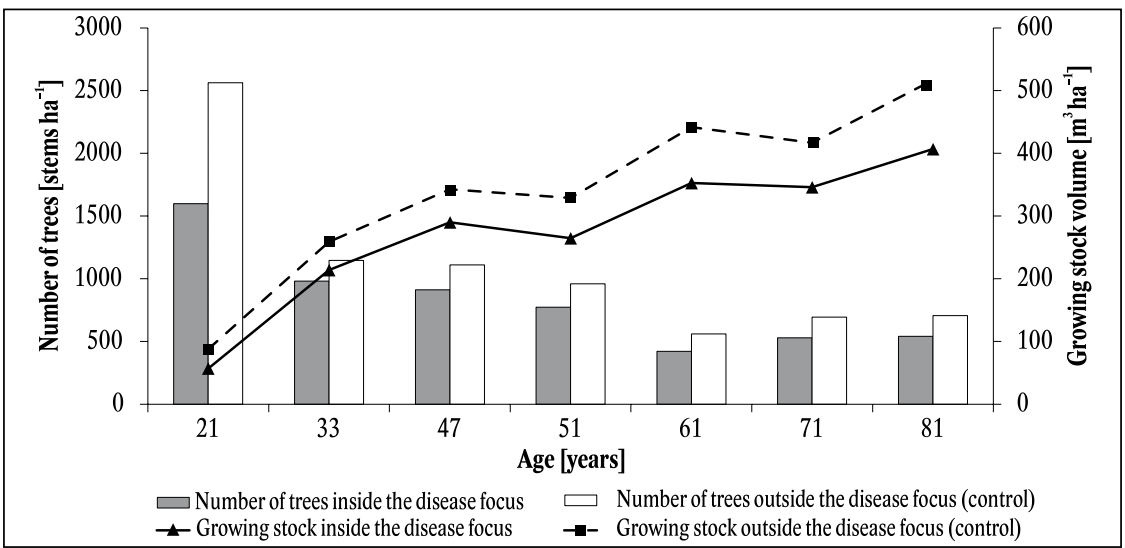

Fig. 5. The number of trees and growing stock volume of pine inside and outside root rot disease foci. 


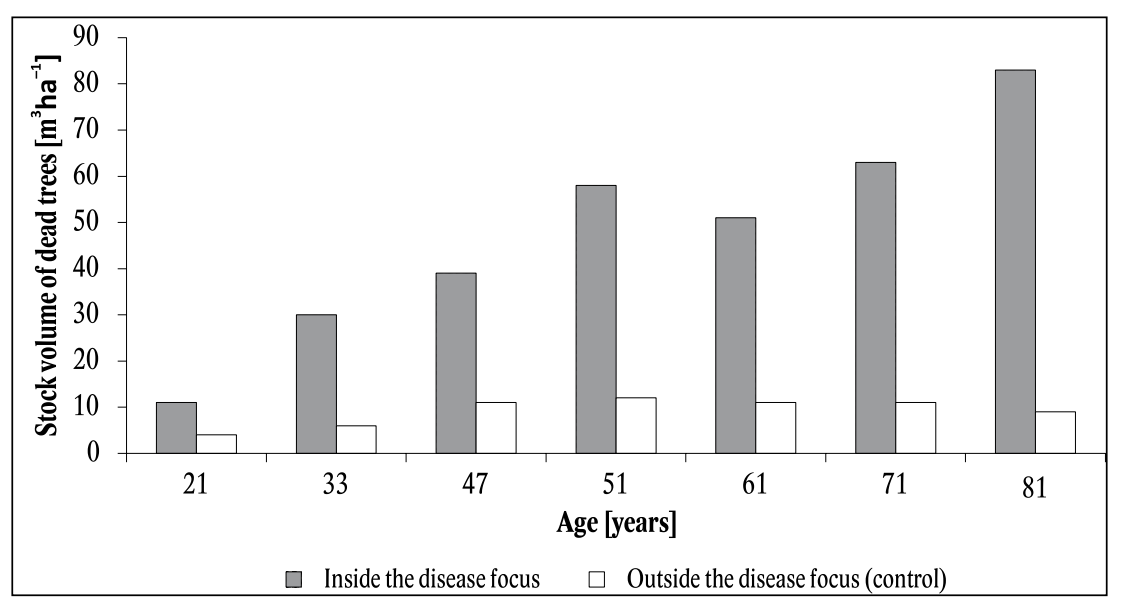

Fig. 6. Stock volume of dead standing trees inside and outside root rot disease foci.

annosum-induced mortality within the disease focus. In general, the part of the stand outside the disease focus had higher site class than the part inside it. The number of dead pine trees in root rot disease focus was 2.5 times larger than in the control, and their stock volume was 4 times greater. The degree of pine damage was medium inside the disease focus and weak outside it. Accordingly, within the disease focus, the pine part of the stand was assessed as "severely weakened" by the health condition $\left(I_{c}=2.6\right)$; in the control, it was "weakened" $\left(I_{c}=1.6\right)$. The birch part of the stand in the disease focus and in the control was assessed as "healthy" $(I=1.0 \ldots 1.1)$.

The density of 49-year-old pine stand within the root rot disease focus (11-DF) was $36 \%$ lower than outside it $(11-\mathrm{C})$ due to the disease-induced mortality. At the same time, the number of dead trees within the disease focus was 1.2 times larger. Lower stands density inside the center caused $3 \%$ excess in average diameter and $1 \%$ excess in average height. The stock volume of living trees was $32 \%$ lower in the disease focus as compared to the control. Instead, the stock of dead trees there was 2.7 times larger. The degree of the stand damage was medium inside the disease focus and weak outside it. Accordingly, the part of the stand inside the root rot disease focus was assessed as "severely weakened" $(I=2.7)$ and the control, as "weakened" $\left(I_{c}=1.7\right)$.

The mixed 48-year-old pine-birch stand (sample plot 10) had a growing stock volume of $284 \mathrm{~m}^{3} \mathrm{ha}^{-1}$. The proportion of Scots pine in the stock was $45 \%$ and the part of the silver birch amounted to $55 \%$. The pine-birch stand had better health and higher productivity compared with those in the disease focus in pure pine stands of the same age (11-DF), planted on the clear-cut after annosuminfected stand (Table 2).

In mixed 49-year-old birch-pine stand (sample plot 12 ), the proportion of silver birch trees was $87 \%$ and Scots pine trees made $13 \%$. Among the birch trees, the healthy ones prevailed ( $80 \%)$. The proportion of dead ones accounted for only $7 \%$ of the total number of trees in the stand. In the pine part of the stand, healthy trees amounted to $48 \%$, weakened and severely weakened ones were estimated at $15 \%$. In this case, the proportion of dead pine trees was $12 \%$. As for health condition, the birch part of the stand was "healthy" $\left(I_{c}=1.5\right)$ and the pine trees were assessed as "weakened" $\left(I_{c}=2.3\right)$.

Thus, the data (Table 2) suggested that in the mixed pine-birch and birch-pine stands, the birch trees had "healthy" condition $\left(I_{c}=1.0 \ldots 1.5\right)$ while pine trees were assessed as "weakened" and "severely weakened" $\left(I_{c}=\right.$ 1.6...2.6).

\section{Discussion}

The results of the study showed that the impact of root rot on the health of the stands can be explained by a set of factors. The factors can include the intensity of pathological dieback; types, values, and timing of forest management actions; the type and the time of development of the dieback foci, etc. Over time, the disease progression leads to a decrease in total increment, the relative density of stocking and total stand volume. For example, the average height of living trees in the root rot disease foci was $2-5 \%$ less and the average diameter was $1-6 \%$ larger compared to the area outside the disease foci. The density of the part of pine stand within the disease foci was much less, by 14-38\%, due to the annosum-induced mortality, and the growing stock volume was 16-35\% lower than that outside the disease foci. The health condition index varied from 2.3 ("weakened stand") to 3.4 ("severely weakened stand") inside the foci of root rot disease and from 1.4 ("healthy stand") to 2.4 ("weakened stand") in the areas outside them.

The tree mortality in the uninfected part of the stand can be mainly attributed to the thinnest trees of the $4^{\text {th }}$ $5^{\text {th }}$ Kraft classes. In the disease focus, not only the trees of the $4^{\text {th }}-5^{\text {th }}$ Kraft classes but also the more developed trees of the $1^{\text {st }}-3^{\text {rd }}$ classes were dying, which are infected by annosum root rot exactly in the same way (Fig. 3). The height of the dead trees inside the root rot foci was $0-8 \%$ 
higher compared to that outside them as in the disease foci the trees with larger diameter were dying. Regardless of the age of the stands, the average diameter and height of dead trees were much smaller than that of living ones. At the same time, in the disease foci, mortality was attributable to considerably thicker and slightly higher trees, in comparison with the control. The more intense opening within the infected part of the stand and, as a result, an increase in the growing space for the trees remaining in this part contributed to their greater growth in diameter and height (Fig. 4).

For the conditions of Ukrainian Eastern Polissya physiographic region, similar results were obtained by other authors (Raspopina et al. 2013). There was a decrease of $20-49 \%$ for the density and of $16-37 \%$ for the growing stock volume of the pine stand in root rot disease foci in comparison with the areas outside the foci due to the disease- and pest-induced mortality. The average height of planted Scots pine stands inside the disease foci was $3 \%$ lower, and the average diameter was $4 \%$ larger than those outside them. In the disease focus, the stand was assessed as "severely weakened" ( $I_{c}$ ranged from 2.6 to 3.4). Intact part of the stand was assessed as "weakened" (I was 1.7-2.4).

The investigation in Ukrainian Novgorod-Siverske Polissya (Lapitan et al. 2013) indicated the decrease in growing stock volume by an average of $24 \%$ and $33 \%$ in root rot disease foci in pre-mature and mature pine stands respectively. According to the data (Vedmid et al. 2013), the growing stock volume and the value of timber of pine stands in Eastern part of Ukrainian Polissya decreased by 1.5-2 times inside the annosum foci as compared to the outside part. In the Volyn Polissya region of Ukraine, the total standing volume and the value of timber of annosum-infected planted pine stands outside the disease foci were $42 \%$ larger than those inside them (Musienko et al. 2018).
The pure pine stands of the next generation, planted on the clear-cuts after annosum-infected pine forests (sample plots 11-DF and 11-C), were considerably exceeded by pure pine stands planted on formerly arable land (sample plots 5-DF and 5-C) in productivity and health. For example, in the disease foci, the growing stock volume in $5-$ DF was $21 \%$ higher than in $11-$ DF (Fig. 7 ). This is attributed to the increasing root rot infection level for the next generation of pure pine stands in already infected areas. The health condition for both test plots was not different during the survey $\left(I_{c}=2.7\right)$.

Mixed pine and birch (sample plot 10) and birch and pine (sample plot 12) stands of approximately equal age had $20 \%$ and $18 \%$ higher growing stock volumes respectively, as compared to the pure pine stand (11DF) planted on clear-cut areas after annosum-infected pine stands. The pine health condition index in the mixed stands was 2.3 ("weakened stand") and in the pure pine stand in the root rot disease focus it was 2.7 ("severely weakened stand"). The birch parts of the stands were healthy $\left(I_{c}\right.$ were 1.4 and 1.5$)$.

In summary, the mixed stands planted on the clearcuts after annosum-infected pine forests exceeded pure pine stands of the same age in growing stock volume. They were more annosum-resistant and had a much better health condition. Therefore, the addition and maintenance of broadleaved species, particularly silver birch, into the stand composition and the timely thinning of young stands can significantly increase the resistance of forests to annosum root rot and prevent the infection. Thus, establishing mixed stands on clear-cut areas after annosum-infected pine forests is justified from the forestry standpoint, due to their higher productivity and better health condition.

According to the study of Raspopina et al. (2013), the growing stock volume of root rot infected pine stands exceeded the growing stock of birch stands by $20 \%$.

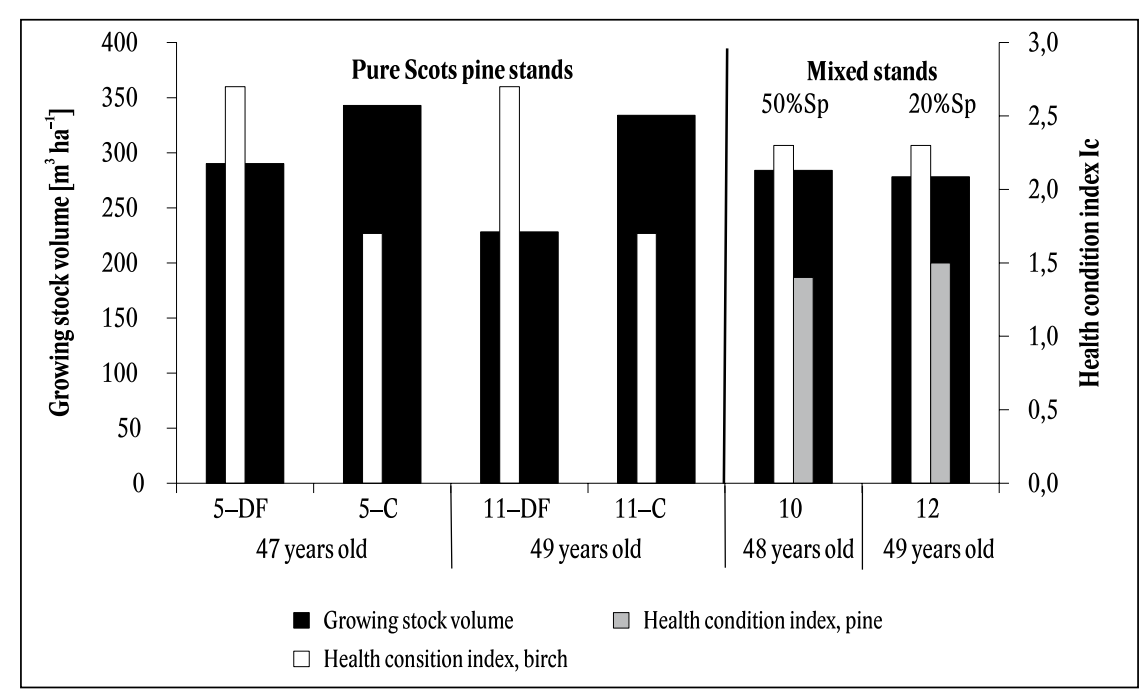

Fig. 7. Growing stock volume and health condition of the investigated pure and mixed stands. 
However, the birch stands had a better health condition $\left(I_{c}=1.6 \ldots .2 .1\right)$ as compared with the infected pine stands $\left(I_{c}=2.6 \ldots 2.9\right)$.

In the opinion of many researchers (Ladeyshchikova et al. 1974; Negrutskiy 1986; Vasilyauskas 1989; Peri et al. 1990; Raspopina et al. 2013), birch stands are more resistant to root rot damage. It is especially advisable to grow pure birch stands in fresh and moist fairly infertile sites on clear-cuts after annosum-infected pine stands, in order to prevent the the disease spreading. In formerly arable lands in fresh fairly infertile pine site type, Alekseev et al. (1981) and Bilous (2006) suggested introducing at least $30 \%$ of silver birch into the composition of pine stand. This could accelerate the decomposition of forest litter and enrich the soil with nitrogen and ash mineral substances.

In the Chernihiv Polissya physiographic region of Ukraine, the growing stock volume of mixed pine and birch stands with $10-20 \%$ of silver birch was $10-35 \%$ higher than that of pure pine stands. Studies in northeastern Poland showed that, in mixed pine stands, the growing stock was on average $41 \%$ larger as compared with pure ones (Bielak et al. 2014). In addition, mixed stands are more resistant to pests and pathogens; they contribute to the enrichment of biodiversity and the improvement of aesthetic and recreational values of forests (Felton et al. 2016).

Planting mixed pine and birch stands will enhance soil and water protection, sanitation, recreation and other beneficial properties of forests and improve the biodiversity of land disturbed by long-term agricultural use (Ladeyshchikova et al. 2001). Additionally, it will contribute to the formation of the natural composition of soil microbiota and will provide the opportunity to grow primary forests in the future.

\section{Conclusions}

The main threat to the pure pine stands planted on the clear-cut areas after annosum-infected pine forests is the danger of re-infestation of the stands. The mixed stands established under these conditions are more resistant to annosum root rot disease and have better health than pure pine ones. The clear-cut areas after annosuminfected pine stands should be reforested using mixed Scots pine and silver birch stands with $30-50 \%$ of Scots pine in the composition.

\section{References}

Alekseev, I. A., Vaskov, S. P., Pokshaeva, N. N., 1981: Creation of resilient pine plantations. In: Protection of conifer stands from root rot: Proceedings of Scientific Conference of Belarus and Baltic Republics, Minsk, 9-10 September, 1981, Minsk, p. 6-7.
Artyukhovskiy, A. K., 2000: Growing of pine in formerly arable land. The Bulletin of Central Black Earth Regional Department of Forest Sciences of Academy of Natural Sciences, Voronezh State Academy of Forestry and Technologies, 3:174-176.

Asiegbu, F.O., Adomas, A., Stenlid, J., 2005: Conifer root and butt rot caused by Heterobasidion annosum (Fr.) Bref. s. l. Molecular Plant Pathology, 6:395-409.

Avery, T. E., Burkhart, H. E., 2002: Forest Measurements. N.Y., McGraw-Hill Pub., 456 p.

Bendz-Hellgren, M., Brandtberg, P.-O., Johansson, M., Swedjemark, G., Stenlid, J., 1999: Growth rate of Heterobasidion annosum in Picea abies established on forest land and arable land. Scandinavian Journal of Forest Research, 14:402-407.

Bielak, K., Dudzińska, M., Pretzsch, H., 2014: Mixed stands of Scots pine (Pinus sylvestris L.) and Norway spruce (Picea abies [L.] Karst) can be more productive than monocultures. Evidence from over 100 years of observation of long-term experiments. Forest Systems, 23:573-589.

Bilous, M. M., 2006: Establishing forest stands on land ubsuitable for agriculture. In: Proceedings of Scientific Conference for Academics, Researchers and Postgraduates, 11-12 April, 2006, Kyiv, p. 66-67.

Brandtberg, P.-O., Johansson, M., Seeger, P., 1996: Effects of season and urea treatment on infection of stumps of Picea abies by Heterobasidion annosum in stands on former arable land. Scandinavian Journal of Forest Research, 11:261-268.

Chudak, V.V., 2014: Information about condition of forests in Polissya and Podillya zones of Ukraine. Available at: http://dklg.kmu.gov.ua/forest/control/uk/ publish/article;jsessionid=0496D5C46F8CDF9F2 64E0C1FC35FC96B.app2?art_id=118307\&cat_ $\mathrm{id}=81209$.

Dai, Y.-C., Vainio, E. J., Hantula, J., Niemelä, T., Korhonen, K., 2003: Investigations on Heterobasidion annosum s.lat. in central and eastern Asia with the aid of mating tests and DNA fingerprinting. Forest Pathology, 33:269-286.

Demchenko, S. I., Sukhomlin, M. N., 2000: Investigation of the antagonistic activity of Peniophora gigantea (Fr.) Mass. for use in biological control of root rot. The Bulletin of Nikitskiy Botanical Garden, 76:52-54.

Fedorov, N. I., 1991: Ecological basis for the protection of pine stands from root rots. In: Protection of forest ecosystems and rational use of forest resources: $2^{\text {nd }}$ All-Union Scientific Conference. Part 1. Moscow, MFTI, p. 147-148.

Felton, A., Nilsson, U., Sonesson, J., Felton, A. M., Roberge, J. M., Ranius, T. et al., 2016: Replacing monocultures with mixed-species stands: Ecosystem service implications of two production forest alternatives in Sweden. Ambio, 45:124-139. 
Garbelotto, M., Gonthier, P., 2013: Biology, epidemiology, and control of Heterobasidion species worldwide. Annual Review of Phytopathology, 51:39-5.

Hammer, O., Harper, D. A. T., Ryan, P. D., 2001: PAST: paleontological statistics software package for education and data analysis. Palaeontologia Electronica, 4:1-9.

Hrom, M. M., 2007: Forest inventory. Lviv, RVV NLTU, $416 \mathrm{p}$.

Kenigsvalde, K., Donis, J., Korhonen, K., Gaitnieks, T., 2011: Biological control of Heterobasidion root rot of coniferous stumps by Phlebiopsis gigantea - literature review. Mežzinātne, 23:25-40.

Kenigsvalde, K., Brauners, I., Korhonen, K., Zaḷuma, A., Mihailova, A., Gaitnieks, T., 2016: Evaluation of the biological control agent Rotstop in controlling the infection of spruce and pine stumps by Heterobasidion in Latvia. Scandinavian Journal of Forest Research, 31:254-261.

Korhonen, K., Capretti, P., Karjalainen, R., Stenlid, J., 1998: Distribution of Heterobasidion annosum intersterility groups in Europe. In: Woodward, S., Stenlid, J., Karjalainen, R., Hüttermann, A. (eds.): Heterobasidion annosum: Biology, Ecology, Impact and Control. Wallingford, CAB International, p. 93-104.

Ladeyshchikova, E. I., Pobegaylo, A. I., Belyy, G. D., Alekseev, I. A., Chernykh, A. G., Pasternak, P. S. et al., 1974: About the predisposing causes to the disease for pine forests on formerly arable lands. In: Ladeyshchikova, E. I., Pobegaylo,A. I., Pasternak, P. S., Ladnykh, L. F. (eds.): Root Rot. Kharkiv, Prapor, p. 22-31.

Ladeyshchikova, O. I., Ustsky, I. M., Chernykh, O. H., Mokrytsky, V. O., Bersneva, L. O. (eds.), 2001: Guideline to protect pine plantations against root rot. Kharkiv, URIFFM, $28 \mathrm{p}$.

Lapitan, O. V., Zhemchuzhin, V. Y., Melnik, T. I., 2013: Components of damage from the root fungus in ripening and mature pine stands of Novgorod-Siverskiy Polyssya. The SNAU Vestnik, 11:14-19.

Lukyanets, V., Lisnyak, A., Tarnopilska, O., Musienko, S., Garbuz, A., Kraynukov, A., 2019: Physical and chemical properties of soils in potential approaches of Volynic Polisse, violated by root rot. Folia Geographica, 61:98-119.

Lyamtsev, N. I., 2015: Findings of root rot studies in the Buzuluksky pine forest. In: Storozhenko, V. G., Zviagintsev, V. B. (eds.): Problems of Forest Phytopathology and Micology: Materials of the IX International conference, 19-24 October, 2015, MinskMoscow-Petrozavodsk, Minsk, BSTU, p. 118-121.

Lygis, V., Vasiliauskas, R., Stenlid, J., Vasiliauskas, A., 2004: Silvicultural and pathological evaluation of Scots pine afforestations mixed with deciduous trees to reduce the infections by Heterobasidion annosum s.s. Forest Ecology and Management, 201:275-285.
Marinich, A. M., Pashchenko, V. M., Shishchenko, P. G., 1985: The nature of the Ukrainian SSR. Landscapes and physiographic mapping. Kyiv, Naukova Dumka, 224 p.

Mashkovsky, V. P., 2015: Commoditization of the rated cutting by assortment tables with tree row distribution according to natural diameter classes. Problems of Forest Science and Forestry: collection of scientific works of Institute of Wood of NAS of Belarus, 75:340-348.

Musienko, S., Luk'yanets, V., Tarnopylska, O., Kobets, O., Babenko, V., 2018: Merchantability and assortment structure of pine stands affected by root rot in the Volyn Polissya region, Ukraine. Central European Forestry Journal, 64:96-103.

Negrutskiy, S. F., 1986: Annosum root rot. Moscow, Agroptomizdat, $196 \mathrm{p}$.

Otrosina, W. J., Garbelotto, M., 2010: Heterobasidion occidentale sp. nov. and Heterobasidion irregulare nom. nov.: a disposition of North American Heterobasidion biological species. Fungal Biology, 114:16-25.

Peri, T., Korhonen, K., Sairanen, A., 1990: Occurrence of Heterobasidion annosum in pure and mixed spruce stands in Southern Finland. Scandinavian Journal of Forest Research, 5:113-125.

Raspopina, S. P., Tarnopilska, O. M., Lukjanets, V. A., Kobets, O. V., 2013: Standing forest and characteristics of soils in focuses of dispersion a pine fungus (Heterobasidion annosum (Fr) Bref.) on abandoned agricultural lands of East Polissya. Scientific Bulletin of UNFU, 23.13:64-73.

Rishbeth, J., 1963: Stump protection against Fomes annosus. III. Inoculation with Peniophora gigantea. Annals of Applied Biology, 52:63-77.

Sanitary Forests Regulations in Ukraine, 2016:Approved by Cabinet of Ministers of Ukraine, Kyiv, 20 p. Available at: http://zakon5.rada.gov.ua/laws/show/55595-\%D0\%BF.

Shvydenko, A. Z., Strochinsky, A. A., Savich, Yu. N., Kashpor, S. N. (eds.), 1987: Regulatory reference materials for forest inventory of Ukraine and Moldova. Kyiv, Urozhay, 559 p.

Sierota, Z., 2013: Heterobasidion root rot in forests on former agricultural lands in Poland: Scale of threat and prevention. Academic Journal, 8:2298-2305.

Stenlid, J., 1985: Population structure of Heterobasidion annosum as determined by somatic incompatibility, sexual incompatibility, and isozyme patterns. Canadian Journal of Botany, 63:2268-2273.

Tarnopilska, O., Musienko, S., Lyalin, O., Tkach, L., Babenko, V., 2018: The effect of alternative thinning regimes on growth and stability of Scots pine plantations in southern forest-steppe in Ukraine. Forestry Ideas, 24:51-72.

Ustsky, I. M., 2011: Soil features of annosum-infected pine stands within Novgorod-Siverskiy Polissya. Lisovyy zhurnal, $2: 48-52$. 
Ustsky, I. M., Taran, T. V., Belous V. P., 2010: Comprehensive assessment of the distribution of forest-pathological processes (differentiated by administrative regions of Ukraine) and the forecast for the distribution of pathological processes in Ukrainian forests by 2015. Kharkiv, URIFFM, 53 p.

Vasiliauskas, A., 1989: Root fungus and the resistance of coniferous forests' ecosystems. Vilnius, Mokslas Publishers, $175 \mathrm{p}$.

Vasiliauskas, R., Juska, E., Vasiliauskas, A., Stenlid, J., 2002: Community of Aphyllophorales and root rot in stumps of Picea abies on clear-felled forest sites in Lithuania. Scandinavian Journal of Forest Research, 17:398-407.

Vedmid, M. M., Tarnopilska, O. M., Kobets, O. V., Zuev, E. S., Lozitsky, V. G., 2013: State, productivity and assortment structure of first generation pine and birch stands cultivated on abandoned agricultural lands of East Polissya. Forestry and Forest Melioration, 122:12-23.

Volchenkova, G. A., Zvyagintsev, V. B., 2011:The development of biological methods to limit the harmfulness of annosum root rot. Collection of scientific papers of the Forest Institute of the National Academy of Sciences of Belarus, 71:445-455.

Volchenkova, G. A. Zvyagintsev, V. B., Krivitskaya, Z. I., Zhdanovich, S. A., 2012: Distribution of centers of infection by Heterobasidion annosum (Fr.) Bref. in the pine stands of Vitebsk, Minsk and Mogilev regions. Proceedings of BSTU, 1:225-228.
Vollbrecht, G., Gemmel, P., Elfving, B., 1994: Forest management with the purpose of reducing windthrow and infection by Heterobasidion annosum in Picea abies - preliminary results from a field experiment. In:Vollbrecht, G.: Effects of silvicultural practices on the incidence of root and butt rot in Norway spruce with special emphasis on Heterobasidion annosum. Doctoral thesis, Swedish University of Agricultural Sciences, Alnarp, Sweden.

Wang, L. Y., 2012: Impact of Heterobasidion spp. root rot in conifer trees and assessment of stump treatment. With emphasis on Picea abies, Pinus sylvestris and Larix $\times$ eurolepis. Doctoral Thesis (Summary). Swedish University of Agricultural Sciences, Alnarp, Acta Universitatis agriculturae Sueciae (1652-6880): 97, $66 \mathrm{p}$.

Woodward, S., Stenlid, J., Karjalainen, R., Hutterman, A. (eds.), 1998: Heterobasidion annosum: Biology, Ecology, Impact and Control. Wallingford, CAB International, $589 \mathrm{p}$.

Worrall, J. J., Harrington, T. C., Blodgett, J. T., Conklin, D. A., Fairweather, M. L., 2010: Heterobasidion annosum and $H$. parviporum in the southern Rocky Mountains and adjoining States. Plant Disease, 94:115-118.

Zvyagintsev, V. B., Volchenkova, G. A., Zhdanovich, S. A., 2013: Silvicultural and forest protection activities in pine stands affected by Heterobasidion annosum (Fr.) Bref. Proceedings of BSTU, 1:223-226. 